\title{
Characteristic of Orangutan Habitat in Coal Mining Rehabilition Area in East Kalimantan, Indonesia
}

\author{
Liza Niningsih $^{1,2^{*}}$, Hadi Sukadi Alikodra ${ }^{3}$, Sri Suci Utami Atmoko ${ }^{4}$, Yeni Aryati Mulyani ${ }^{3}$ \\ ${ }^{1}$ Graduate School of Bogor Agricultural University, Campus IPB Dramaga, Bogor, Indonesia 16680 \\ ${ }^{2}$ Department of Forestry, Kutai Timur College of Agricultural, Sangatta, Kutai Timur, Indonesia 75683 \\ ${ }^{3}$ Department of Conservation of Forest Resources and Ecosystem, Faculty of Forestry, \\ Bogor Agricultural University, Campus IPB Dramaga, PO Box 168, Bogor, Indonesia 16680 \\ ${ }^{4}$ Faculty of Biology, Nasional University, Pasar Minggu, Jakarta, Indonesia 12520
}

Received September 5, 2016/Accepted April 25, 2017

\begin{abstract}
The majority of wild orangutans are found outside of the protected areas, including in coal mining areas which generally overlapping with orangutan habitat. Thereby, mining ensured a direct impact on orangutans. Opportunities orangutans to survive in the mining area depends on various factors, one of them is the ability of orangutan to adapt to habitat change. We investigated habitat characteristics in the coal mining area consist of land cover types, species composition, and the structure of vegetation. Data were collected from April to September 2014 in the coal mining rehabilitation area (CMRA) of PT KPC in East Kutai. Mining caused the natural habitat fragmented into smaller patches in the form of CMRA and natural forests remaining. The forest stand in CMRA compiled by the small trees of the same species and age class. It caused the canopy is not always continue. Food trees and nest trees were limited in CMRA. Exotic species dominated in CMRA, namely: Senna siamea, Falcataria moluccana, and Senna surattensis. CMRA is not the good habitat for orangutan if seen from the aspect of either structure or vegetation composition. The quality of habitat can be improved by modifying the structure and vegetation composition, build the ecosystem corridors, increase public awareness, and involve various stakeholders at the landscape level.
\end{abstract}

Keywords: Pongo pygmaeus morio, forest structure, food tree, nest tree, conservation

*Correspondence author,email: lizani_pili@yahoo.com,phone:+62-81346216757

\section{Introduction}

Bornean orangutan faces a high risk of extinction in the wild due to $\pm 78 \%$ of the wild population found outside of protected areas, namely: $29 \%$ in logging concessions, $19 \%$ in oil palm plantation concession, $6 \%$ in industrial timber plantation concessions, and $24 \%$ outside concessions (Wich et al. 2012). The main threats to the orangutan survival are habitat loss, habitat degradation, forest fires, habitat fragmentation, illegal hunting, lack of awareness, and climate change (Meijaard et al. 2001; Ancrenaz et al. 2016). Based on spatial models, Struebig et al. (2015) predicted many of orangutan habitat is no longer suitable in the future because of climate change. The number of bornean orangutan population is not precisely known. Wich et al. (2012) estimated the number of bornean orangutan populations are 104,700 in an area of $\pm 155,000 \mathrm{~km}^{2}$, the populations predicted are continuously declining to 47,000 orangutans in 2025. If there are no right conservation efforts, within the next 50 years many populations will be decreased or become extinct (Abram et al. 2015). The combined impacts of habitat loss, habitat degradation, and illegal hunting have caused the bornean orangutan populations declined sharply so that the bornean orangutan has been upgraded from "endangered" category becomes "critically endangered" on the Red List of Threatened Species IUCN (Ancrenaz et al. 2016).

Expansion of the area for economic development in many sectors can not be prevented because the human population continues to increase. It poses a major threat to orangutans and another species, either through the direct cause such as hunting and killing as well as the indirect causes such as degradation and fragmentation of habitats (Meijaard et al. 2001; Hockings \& Humle 2010; Soehartono et al. 2009). The coal mining areas in East Kalimantan developed rapidly after the weakening of the era of forests exploitation and the timber industries. Since that time, the mines sector has been a major driver of economic development in East Kalimantan. East Kutai Regency has the largest coal reserves (52.67\%), followed by Kutai Kertanegara (21.01\%), and smaller reserves distributed in other regencies/cities. Interpretation of Landsat imagery in 2014 showed that the land has been used for mining only $0.7 \%$ of $22,410.51$ ha of the total area of 
East Kutai or $\pm 20 \%$ of the total area of the mining concession permits. Although the mining areas are relatively smaller than oil palm plantations which reached 296,119.33 ha $( \pm 9.28 \%)$, the impact of open pit mining on biodiversity could result in tremendous damage.

Coal mining concessions in East Kalimantan are generally overlapping with orangutan habitat. Thereby, operations and infrastructure development ensured a direct impact on orangutans. Opportunities orangutans to survive in the coal mining area depends on various factors, one of them is the ability of orangutan to adapt, especially to changes in food resources. According to Campbell et al. (2008), foraging behavior and mating behavior can affect the fitness of animals directly, whose success is strongly influenced by moving behavior. In the habitats has changed, behavioral flexibility is very important for animals because it can improve the fitness of the animals that lived in the area (Reader \& MacDonald 2003; Sol 2003). Psychological research showed that orangutans have the mental qualities to adapt to habitat changes, since orangutans are able to learn, make conclusions, set up and dismantle the equipment, have long-term memory, and it can understand the environment signs (Meijaard et al. 2001). In a certain degree, bornean orangutan (Pongo pygmaeus) has an ability to survive in the degraded habitat. For example, changes diet from fruit to an alternative food (fallback food) such as bark (Ancrenaz et al. 2007) and increases the terrestrial activity in a habitat which impaired canopy of anthropogenic (Ancrenaz et al. 2004). KPC (2011) and Rayadin and Spehar (2015) have confirmed the existence of orangutan population in the coal mining area, especially in any coal mining rehabilitation areas in East Kutai. During our research, we have documented 39 different individuals in the nine rehabilitation areas. They consist of $17.95 \%$ adult males, $38.45 \%$ adult females, $10.26 \%$ adolescents, and $23.08 \%$ infants). It's confirmed that bornean orangutan has an ability to adapt in those areas.

The aim of this research is to describe the characteristics of bornean orangutan (Pongo pygmaeus morio) habitat in the coal mining rehabilitation areas about changes in land cover, floristic composition, forest structure, food plants, and nest trees.

\section{Methods}

Study site The research was conducted in Coal Mining Rehabilition Area of PT Kaltim Prima Coal, which is well known as CMRA, East Kutai Regency, East Kalimantan Province, Indonesia. Data were collected from April to September 2014 which focused on Taman Payau CMRA $\left(0^{\circ}\right.$ $\left.36^{\prime} 58^{\prime \prime} \mathrm{N}, 117^{\circ} 30^{\prime} 58^{\prime \prime} \mathrm{E}\right)$ and Gajah Hitam CMRA ( $0^{\circ} 33^{\prime}$ $\left.26^{\prime \prime} \mathrm{N}, 117^{\circ} 30^{\prime} 32^{\prime \prime} \mathrm{E}\right)$. The both CMRAs are the land reclamation of coal mines which planted more than 10 years (Figure 1).

Data collection Variables which are used to describe habitat characteristics of orangutan habitat in CMRA consist of land cover types, species composition of trees with diameter at breast height (dbh) $\geq 5 \mathrm{~cm}$ (excluding shrubs), the vertical and horizontal structure of forest stand, orangutan food tree, and orangutan nest tree.
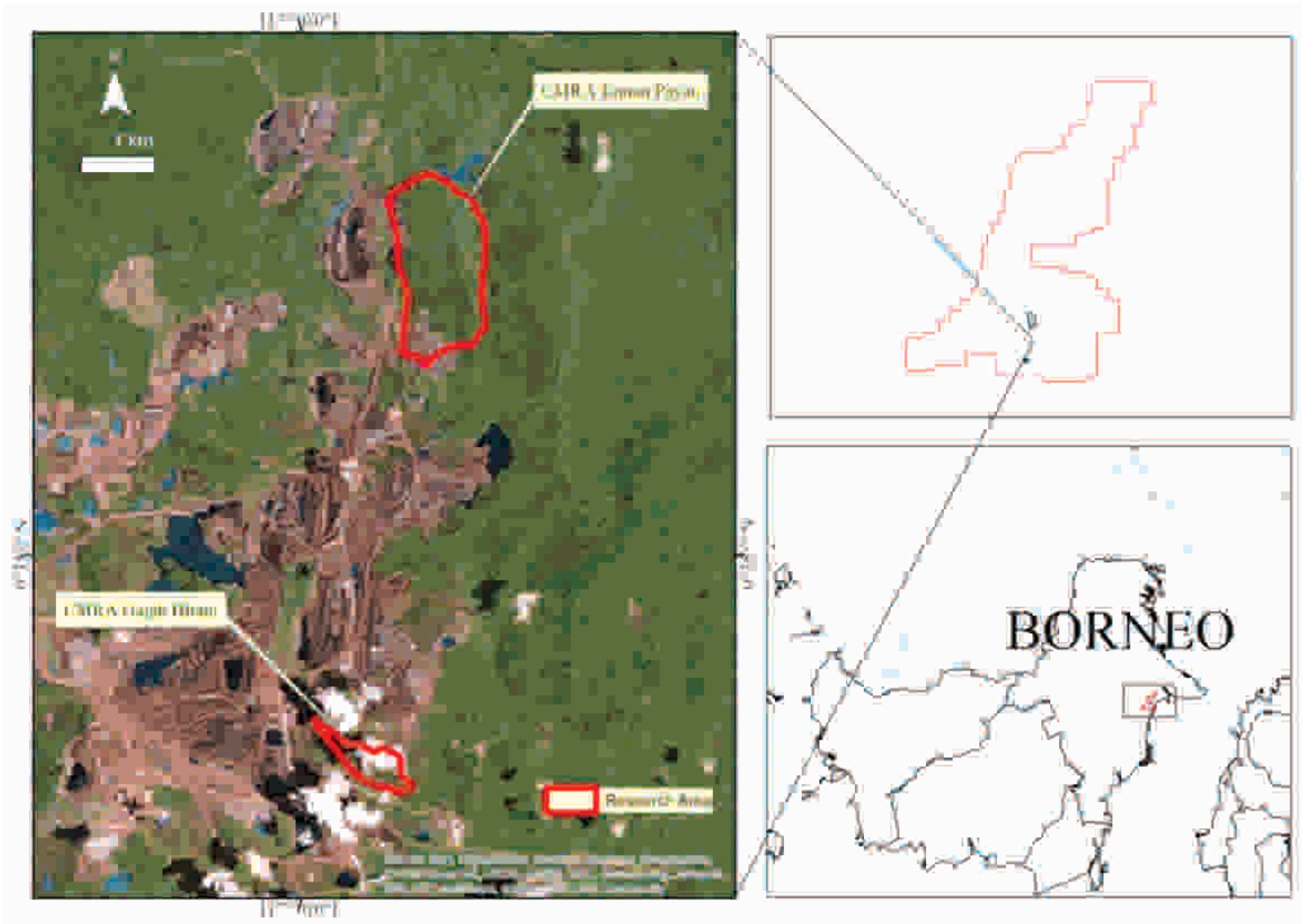

Figure 1 Location of coal mining study area. 
The data of land cover types was obtained through remote sensing, the method used was a visual classification to four Landsat imagery 8 path/row $116 / 59$ acquisitions February 7 th and March 11th, 2014 and path/row 116/60 acquisitions February 7 and July 1st, 2014. Four imageries were used to eliminate the appearance of clouds and cloud shadows on each imagery.

The trees composition data collection used a botanical sample plot of 0.2 ha $(100 \mathrm{~m} \times 20 \mathrm{~m})$ in each CMRA. Sample plots were developed purposively. Each plot was subdivided into $20 \mathrm{~m} \times 20 \mathrm{~m}$ quadrat for easy sampling of trees (dbh $\geq 5 \mathrm{~cm}$ ). Thus, we used the total botanical plot of 0.4 ha and quadrats of trees were 10 quadrats. The total area of 0.4 ha sample plots have been considered to represent the condition of the forest stand was relatively homogeneous. We have recorded the species, number, and dbh of all trees $(\mathrm{dbh} \geq 5$ $\mathrm{cm}$ ) for each quadrat. We also recorded species of plants lifestyles/habitus other than trees found in the study area. An expert helped for identified species. If possible, we identified each plant to species level or to genera level when the species could not be identified. Most of the trees in CMRA is not difficult to identify the species because these trees were cultivated and their species were known clearly.

The structure data collection used the same botanical plot. We were determined the number, total height (h), diameter at breast height (dbh), height of clear bole (hcb), the height of maximum crown width (hmcw), and the crown width of all tree species in each quadrat (Harja \& Vincent 2008). We measured dbh using a phi band. We measured h, hcb, mcw, and crown width using a laser distance meter and a tape measure. Crown diameter was measured in two perpendicular directions. Crown projection diameter was first measured along maximum crown width axis and then perpendicularly to this first direction. The average was used for crown width. The radius projection of crown measured with eight radiuses to get a more accurate prediction of crown width. Tree parameters to be measured can be seen in Figure 2.

The data of food tree for orangutan was obtained based on the direct observation, the worker interview, and observed the after-eating signs of orangutan. Data of nest tree obtained based on direct observation by looking at the existence of
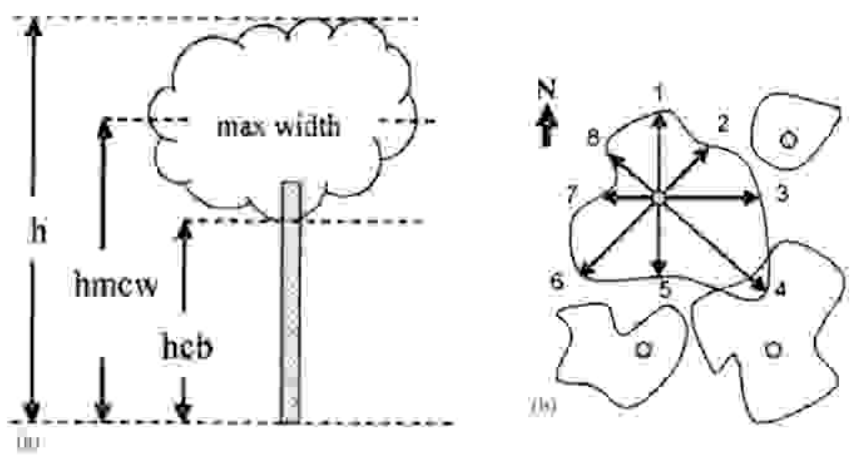

Figure 2 (a) Height measurement and (b) crown radius measurement (Harja \& Vincent 2008). nests on trees. The data of food tree for orangutan is obtained based on the direct observation, the worker interview, and observed the after-eating signs of orangutan. Data of nest tree obtained based on direct observation by looking at the existence of nests on trees.

Data analysis We used spatial analysis with the geographic information system to determine the characteristics of the land cover in the study area. Visual classification is used to classify the homogeneous appearance, and then we interpret based on the elements that are recorded on an imagery (color, hue, texture patterns, shapes, sizes, as well as their association with the other land cover). Vegetation analysis is used to determine the composition of vegetation, abundance and distribution of the nest trees, food trees, and other food sources.

Vegetation species diversity and its distribution are the useful variables to assess habitat quality. A good orangutan habitat is usually in the forms of small forest slot mosaic with its different species of woody plants, it also has species fruit trees. Vegetation analysis is used to gain species composition, the tree density (D), frequency (F), basal area (BA), and important value index (IVI). The D of a species is a count of the number of individuals of a species within the botanical plot. Afterwards, the sum of D is calculated in terms of species density per hectare. The $\mathrm{F}$ is the probability or chance of finding a species in a given sample area. The BA per tree was formulated with $0.25 \pi \mathrm{d}^{2}$ in which $\mathrm{d}$ is the $\mathrm{dbh}$ and $\pi$ is the constanta (3.1416). The BA $\left(\mathrm{m}^{2} h \mathrm{a}^{-1}\right)$, was calculated by summing the BA of all trees found within the botanical plot.

The IVI is the pattern of calculation used to determine the dominant vegetation ecologically for each level of growth in every observation plot. It is the result of summation of relative density $(\mathrm{RD}, \%)$, relative frequency $(\mathrm{RF}, \%)$, and relative basal area (RBA, \%) (Curtis 1959). The $\mathrm{RD}=\mathrm{D}$ of a species/total $\mathrm{D}$ of all species $\times 100$. The $\mathrm{RF}=\mathrm{F}$ of $\mathrm{a}$ species/sum of $F$ of all species $\times 100$, The RBA $=$ BA of a species/total BA of all species x 100 .

The architecture profile analysis is used to obtain the description of vertical and horizontal structure of forest. The structure of forest stand was described in the form of architecture profile by projecting the result of tree measurement, i.e., the total height, clear bole, the canopy diameter, and the position of a tree in the botany plot. The parameters derived from measurement were processed by using the software SexI-FS (Spatially Explicit IndividualBased Forest Simulator), 2.1.0 version to describe the vertical and horizontal structure of forest stand (Harja \& Vincent 2008). We divided the height of the canopy into 5 of high-class, namely: $5 \mathrm{~m}, 5-10 \mathrm{~m}, 10-15 \mathrm{~m}, 15-20 \mathrm{~m}$, and $>20 \mathrm{~m}$. We also drew the canopy into five layers: $\mathrm{A}(>30 \mathrm{~m})$, B $(20-30 \mathrm{~m}), \mathrm{C}(4-20 \mathrm{~m}), \mathrm{D}(1-4 \mathrm{~m})$, and $\mathrm{E}(0-1 \mathrm{~m})$ (Soerianegara \& Indrawan 1998).

\section{Results and Discussion}

Overall study sites Coal mining area adjacent to the Prevab Orangutan Research Station of the Kutai National Park. Both locations are separated by the Sangatta River as the northern boundary of the Kutai National Park (KNP). 
Taman Payau CMRA is reclamation planted in 1998 with an area of 162.74 ha, while Gajah Hitam CMRA planted in 2002 and it has an area of 22.97 ha. Based on SchmidtFerguson climate classification, study areas including type $\mathrm{A}$ is very wet. Annual rainfall was in the range of $1,549.5-2,993.4 \mathrm{~mm}$ with mean annual was $2,558 \mathrm{~mm}$. The mean annual temperature was $26^{\circ} \mathrm{C}$ between $21^{\circ} \mathrm{C}$ and $34^{\circ} \mathrm{C}$, The normal wind speed was 2-4 knot hour ${ }^{-1}$ (Ferisa 2014; KPC 2015).

During 2014, Gajah Hitam CMRA suffered nine wet months and three moist months, the average rainfall per rain day was $13.42 \mathrm{~mm}$. Mean monthly rainfall in Gajah Hitam CMRA was $188.2 \mathrm{~mm}$, ranging from $73.0 \mathrm{~mm}$ (six rain days) in October until $376.5 \mathrm{~mm}$ (19 rain days) in December. Taman Payau CMRA has 10 wet months, one moist months, and one dry months in 2014, maximum rainfall in December (536.0 $\mathrm{mm}$ and 21 rain days), while minimum rainfall in October ( $35.0 \mathrm{~mm}$ and 3 rain days). These data were the result of measurement in the study site in 2014, derived from the Environment Department of PT KPC.

Land cover Interpretation of landsat coverage in 2014 showed that the orangutan habitat in the coal mining area has undergone constriction and fragmentation within a period of $>30$ years. Mining and construction of supporting infrastructure have changed the wet rain forest intact and compact into smaller and isolated patches. Mining activities have led partly of orangutan habitat were lost, and the remaining area is divided into smaller habitat fragment. Of the 90,938 ha concession area of PT KPC, the total area that has been mined is $\pm 26 \%$ (24,553.19 ha). The land cover of the $26 \%$ PT KPC areas have been mined has presented in Figure 3 and Table 1.

Comparison of land cover by Sihombing (2012) in two periods (2002 and 2012) in the coal mining area of PT KPC showed the degradation of the land cover quality. It is

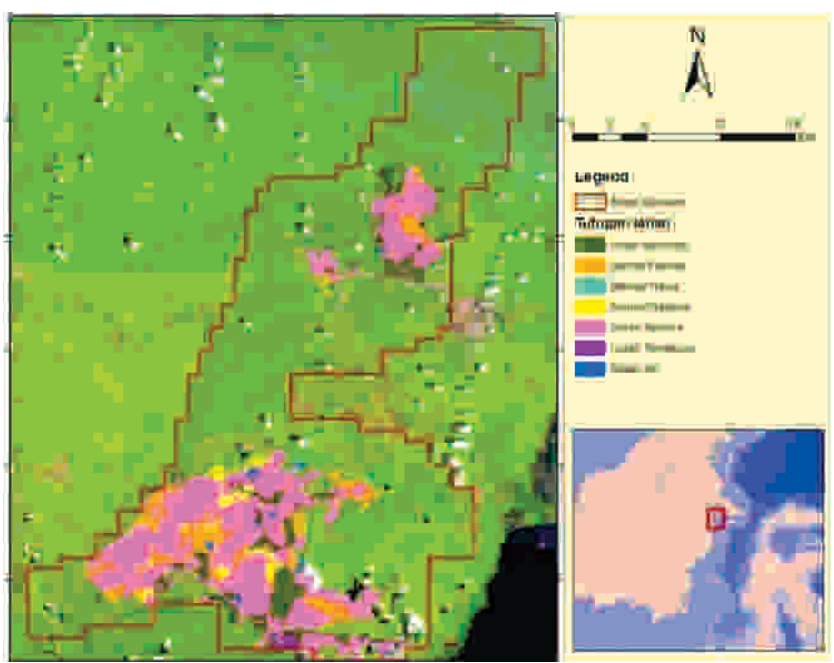

Figure 3 Land cover map in the coal mining area of PT KPC in 2014. evidenced by the increase in the total degraded area (Table 2).

The combined impact of habitat constriction and fragmentation be able to cause the collapse of the ecosystem as a whole (Gunawan \& Prasetyo 2003), this case applies to orangutan habitat in the coal mining area. According to Forman (1995), fragmentation begins with dissection, then perforation, fragmentation, and habitat attrition, which causing the habitat becomes unsuitable or have a low suitability. Habitat degradation in the coal mining area started with dissection when the road network built for coal exploration, followed by perforation when concession holders started exploitation coal. In line with the increased production capacity and growing extent of disturbed areas, the frequency of small bags habitat has increased, so fragmented habitats dominated the landscape in the coal mining area. Further small habitat remaining suffered attrition, become smaller and isolated.

Reclamation and revegetation by concessionaires led to the emergence of new bags habitat, it has the structure and floristic composition is very different from the natural habitat. Ultimately, coal mining operations have produced a landscape with some land cover types, namely: remaining natural forests, CMRA forest with trees $\mathrm{dbh} \geq 5 \mathrm{~cm}, \mathrm{CMRA}$ with small trees $(\mathrm{dbh}<5 \mathrm{~cm})$, pit, road network, office area, water, etc.

Land cover changes have caused a large negative impact on the orangutans and another biodiversity. Despite massive habitat destruction occurred in coal mining area, orangutans are known to survive in patches of natural forest remaining and have confirmed colonize some CMRA. The remaining natural forests in the mining area generally have lost the big trees which are very important for the orangutan as food resources and place to build the nest. The structure and floristic composition in CMRA are tended to be similar, almost the same as the forest plantations. Floristic composition and structure of forest stands in CMRA will be described hereinafter.

Floristic composition Most of the total numbers of trees which frames the forest stand in Taman Payau CMRA and Gajah Hitam were trees from exotic species $(79.83 \%)$ and there was only $20.17 \%$ of local species. There were at least 18 species of tree from 16 genera and 9 different families met in both botany plots. The both study plots are dominated by johar (Senna siamea) Johar has the highest density (405 trees $\left.\mathrm{ha}^{-1}\right)$, the biggest basal area $\left(2.15 \mathrm{~m}^{2} \mathrm{ha}^{-1}\right)$, and the most prevalent distribution. Summary of botanical analysis of trees $(\mathrm{dbh} \geq 5 \mathrm{~cm})$ in Taman Payau CMRA and Gajah Hitam is presented in Table 3, while the analysis results in each CMRA is presented in Table 4 and Table 5.

Some species of trees in Taman Payau CMRA and Gajah Hitam have a very low density and distributed randomly, that was why these species were not found in the botanical plot. A number of species found within study plot of Taman Payau are 9 species from 9 genera and 7 families, while outside the plot, there are 8 species of trees, namely: S. surattensis, Vitex pinnata, Acasia auriculiformis, Terminalia catappa, Swietania mahagoni, Delonix regia, Gmelina arborea, and Hibiscus macrophylla. Thus, in Taman Payau CMRA, there are minimum 17 species of trees from 16 genera and 12 
Table 1 Land cover types in the mined area (26\% of PT KPC concession) based on interpretation of Landsat 2014

\begin{tabular}{lrc}
\hline Disturbed area & Area (ha) & Area (\%) \\
\hline Water & 458.96 & 1.87 \\
Swamp & 30.60 & 0.12 \\
Secondary forest (including CMRA) & $4,462.49$ & 18.17 \\
Built -up land & 129.30 & 0.53 \\
Bare soil & $14,610.61$ & 59.51 \\
Grassland mosaic & $1,348.98$ & 5.49 \\
Shrub & $3,512.24$ & 14.30 \\
\hline Total & $24,553.19$ & 100.00 \\
\hline
\end{tabular}

Tabel 2 Comparison of land cover 2002 with 2012 (ha) in the mining area of PT KPC, Sangatta (Sihombing 2012)

\begin{tabular}{lrcc}
\hline Land cover types & \multicolumn{1}{c}{2002} & \multicolumn{1}{c}{2012} & Total change \\
\hline Secondary forest & $16,302.79$ & $11,742.45$ & $-4,560.34$ \\
Shrub & $10,775.97$ & $10,891.73$ & +115.76 \\
Mangrove & $1,685.59$ & $1,349.51$ & -336.08 \\
Swamp & 0.00 & 441.94 & +441.94 \\
Water & 0.00 & 290.95 & +290.95 \\
Built-up land & 893.26 & $1,443.24$ & +549.98 \\
Bare soil & $3,948.31$ & $7,646.90$ & $+3,698.59$ \\
\hline Note: Area of analysis $=33,806.72,-=$ Area reduce,$+=$ Area increase
\end{tabular}

families. This number is more than that of research conducted by Rayadin (2012) which only found three species of trees within botany plot in which the width was the same as Taman Payau CMRA. The number of tree species found within the botany plot of Gajah Hitam were 11 species from 10 genera and 8 families, while outside the botany plot, there were eight species of trees, namely: A. auriculiformis, Ficus sp., Geunsia pentandra, Mallotus dispar, Neolamarckia cadamba, Samanea saman, Syzygium sp., and V. pinnata. Thus, there were minimum 19 species of trees from 17 genera and 11 different families in Gajah Hitam CMRA.

The research results in CMRAs showed that the orangutan habitat were lack of tree species compared to its natural habitat. Niningsih (2009) recorded that there are 78 species consisting 59 genera and 35 families in natural habitat in Prevab Area KNP, while Wahyudi (2009) found there are 98 species from 82 genera and 38 families in that area. In general, orangutans prefer natural habitat, intact, and have the higher food availability (van Schaik 2001; Soehartono et al. 2009). The higher the diversity of vegetation, it will provide food more abundant and varied for orangutans. Changes in composition floristic ensured a serious impact on orangutans. In CMRA, only five of the 28 species that are orangutan food trees. Yet, five of these species were not the dominant in CMRA, even three species of them confirmed were not important food trees for the orangutan (Niningsih et al. 2016), it was because orangutan prefers fruits with soft pulp (Meijaard et al. 2001; Kanamori et al. 2010). Orangutans have to adjust their food composition on species available in the mining area to survive (Campbell et al. 2008). According to Suhud and Saleh (2007), if fruits availability is reduced in an area, the orangutan will migrate to other areas or they try to adapt to change their feeding behavior as an adaptation to environmental changes. Twenty three of the total 28 species found in the both CMRAs are cultivated and the others growing naturally. Trees growing naturally were pioneer trees, such as, Macaranga gigantea, M. hypoleuca, and Mallotus dispar. Soendjoto et al. (2014), recorded a lot of plant species growing naturally are able to grow and progressed in less than two years after reclamation and revegetation on the reclaimed coal mining land of PT Adora Indonesia, because their seeds, rhizomes, or seedlings are dormant on the surface and in the top soil. According to Whitmore (1975), the seed dispersion of pioneer tree species is very effective. Pioneer species is often characterized as having early and frequent flowering and the copious production of small and easily dispersed seeds (Swaine \& Whitmore 1988). Pioneer species vary in a range of ecophysiological and demographic traits, yet many species successfully colonize and co-occur in the forest (Davies 1998). The pioneer species that grown naturally can use as an indicator that the succession in progress in CMRAs.

Non-tree vegetation in CMRAs are also the important habitat component for any wild animals as food source and cover. It was grew both cultivated and naturally. Whereby, the result its showed in Table 6 .

Food plant Orangutans were primarily frugivorous, spending a majority of their total foraging time feeding on fruits (Morrogh-Bernard et al. 2009). The fruit was preferred over leaves and vegetable matter (Bastian et al. 2010). Orangutans in Danum Valley spent $60.9 \%$ of the feeding times on fruits (Kanamori et al. 2010). Orangutan at Tuanan River Lading spent $71 \%$ and $61 \%$ of their total foraging time 
Table 3 Summary of botanical analysis of trees $(\mathrm{dbh} \geq 5 \mathrm{~cm})$ in CMRA Taman Payau and Gajah Hitam

\begin{tabular}{llrrrr}
\hline Species & Family & RD & RF & RBA & IVI \\
\hline Senna siamea Lam. & Fabaceae & 46.02 & 16.67 & 36.00 & 98.69 \\
Falcataria moluccana (Miq.) & Fabaceae & 8.81 & 16.67 & 46.85 & 72.32 \\
Senna surattensis (Burm.f.) & Fabaceae & 21.88 & 8.33 & 7.81 & 38.02 \\
Mallotus dispar (Blume) & Euphorbiaceae & 11.36 & 8.33 & 5.05 & 24.75 \\
Macaranga gigantea (Rchb.f.\&Zoll.) & Euphorbiaceae & 1.42 & 8.33 & 0.34 & 10.10 \\
Ficus uncinata (King) Becc. & Moraceae & 1.99 & 6.67 & 0.52 & 9.18 \\
Croton argyratus Blume & Euphorbiaceae & 1.14 & 6.67 & 0.50 & 8.30 \\
Vernonia arborea $\quad$ Buch. -Ham & Asteraceae & 1.99 & 5.00 & 0.54 & 7.53 \\
Samanea saman (Jacq.) Merr. & Fabaceae & 1.42 & 5.00 & 0.71 & 7.13 \\
Hopea seminis Slooten & Dipterocarpaceae & 1.14 & 3.33 & 0.21 & 4.68 \\
Carallia suffruticosa Ridl. & Rhizophoraceae & 0.57 & 3.33 & 0.08 & 3.98 \\
Syzygium hirtum (Korth.) & Myrtaceae & 0.57 & 1.67 & 0.37 & 2.60 \\
Artocarpus heterophyllus $\quad$ Lam & Moraceae & 0.28 & 1.67 & 0.60 & 2.55 \\
Cratoxylum sumatranum (Jack) Blume & Hypericaceae & 0.28 & 1.67 & 0.12 & 2.07 \\
Macaran ga hypoleuca (Rchb.f.\&Zoll.) & Euphorbiaceae & 0.28 & 1.67 & 0.12 & 2.07 \\
Alstonia scholaris (L.) R. Br. & Apocynaceae & 0.28 & 1.67 & 0.08 & 2.03 \\
Leucaena leucocephala (lam.) de Wit & Fabaceae & 0.28 & 1.67 & 0.07 & 2.02 \\
Guioa pleuropteris (Blume) Radlk. & Sapindaceae & 0.28 & 1.67 & 0.04 & 1.99 \\
\hline
\end{tabular}

Note : RD (relative density), RF (relative frequency), RBA (relative basal area), IVI (important value indeks of trees)

Table 4 Summary of botanical analysis of trees $(\mathrm{dbh} \geq 5 \mathrm{~cm})$ in CMRA Taman Payau

\begin{tabular}{|c|c|c|c|c|c|}
\hline Species & Family & $\mathrm{RD}$ & RF & RBA & IVI \\
\hline Senna siamea Lam. & Fabaceae & 38.17 & 15.63 & 40.74 & 94.53 \\
\hline Falcataria moluccana (Miq.) & Fabaceae & 11.45 & 15.63 & 41.04 & 68.12 \\
\hline Mallotus dispar (Blume) & Euphorbiaceae & 30.53 & 15.63 & 12.62 & 58.78 \\
\hline Macaranga gigantea (Rchb.f. \& Zoll.) & Euphorbiaceae & 3.82 & 15.63 & 0.86 & 20.30 \\
\hline Ficus uncinata (King) Be cc. & Moraceae & 5.34 & 12.50 & 1.31 & 19.15 \\
\hline Vernonia arborea Buch. -Ham & Asteraceae & 5.34 & 9.38 & 1.35 & 16.07 \\
\hline Samanea saman (Jacq.) Merr. & Fabaceae & 3.82 & 9.38 & 1.76 & 14.96 \\
\hline Alstonia scholaris $\quad$ (L.) R. Br. & Apocynaceae & 0.76 & 3.13 & 0.21 & 4.10 \\
\hline Guioa pleuropteris (Blume) Radlk. & Sap indaceae & 0.76 & 3.13 & 0.11 & 4.00 \\
\hline
\end{tabular}

Note : RD (relative density), RF (relative frequency), RBA (relative basal area), IVI (important value indeks of trees)

Table 5 Summary of botanical analysis of trees $(\mathrm{dbh} \geq 5 \mathrm{~cm})$ in CMRA Gajah Hitam

\begin{tabular}{llrrrr}
\hline Species & Family & RD & RF & \multicolumn{1}{c}{ RBA } & IVI \\
\hline Senna siamea & Fabaceae & 50.68 & 17.86 & 32.84 & 101.37 \\
Falcataria moluccana & Fabaceae & 7.24 & 17.86 & 50.71 & 75.81 \\
Senna surattensis & Fabaceae & 34.84 & 17.86 & 13.02 & 65.72 \\
Croton argyratus & Euphorbiaceae & 1.81 & 14.29 & 0.83 & 16.93 \\
Hopea seminis & Dipterocarpaceae & 1.81 & 7.14 & 0.35 & 9.30 \\
Carallia suffruticosa & Rhizophoraceae & 0.90 & 7.14 & 0.13 & 8.18 \\
Syzygium hirtum & Myrtaceae & 0.90 & 3.57 & 0.62 & 5.09 \\
Artocarpus heterophyllus & Moraceae & 0.45 & 3.57 & 0.99 & 5.02 \\
Cratoxylum sumatranum & Hypericaceae & 0.45 & 3.57 & 0.20 & 4.22 \\
Macaranga hypoleuca & Euphorbiace ae & 0.45 & 3.57 & 0.20 & 4.22 \\
Leucaena leucocephala & Fabaceae & 0.45 & 3.57 & 0.12 & 4.14 \\
\hline
\end{tabular}

Note: RD (relative density), RF (relative frequency), RBA (relative basal area), IVI (important value indeks of trees) 
Table 6 Vegetation other than trees observed in CMRA Taman Payau and Gajah Hitam

\begin{tabular}{|c|c|c|c|c|}
\hline Species & Family & Habitus & Native & Planting \\
\hline Ardisia villosa & Myrsinaceae & Liana & $\sqrt{ }$ & \\
\hline Caladium sp. & Araceae & Taro & $\sqrt{ }$ & \\
\hline Calliandra calothyrsus & Fabaceae & Schrub & & $\sqrt{ }$ \\
\hline Calopogon ium coeruleum & Fabaceae & Liana & & $\sqrt{ }$ \\
\hline Centrosema acutifolium & Fabaceae & Liana & & $\sqrt{ }$ \\
\hline Costus speciosus & Zingiberaceae & Ginger & $\sqrt{ }$ & \\
\hline Derris sp. & Fabaceae & Liana & $\sqrt{ }$ & \\
\hline Desmodium triflorum & Fabaceae & Liana & & \\
\hline Dillenia suffruticosa & Dilleniaceae & Schrub & $\sqrt{ }$ & \\
\hline Hornstedtia minor & Zingib eraceae & Ginger & $\sqrt{ }$ & \\
\hline Melastoma malabathricum & Melastomataceae & Schrub & $\sqrt{ }$ & \\
\hline Merremia peltata & Convolvulaceae & Liana & $\sqrt{ }$ & \\
\hline Poikilospermum suaveolens & Urticaceae & Liana & $\sqrt{ }$ & \\
\hline Saccharum spontaneum & Poaceae & Herbaceous & $\sqrt{ }$ & \\
\hline Spatholobus ferrugineus & Fabaceae & Liana & $\sqrt{ }$ & \\
\hline Piper ad uncum & Piperaceae & Schrub & $\sqrt{ }$ & \\
\hline Loranthus sp. & Loranthaceae & Epifit & $\sqrt{ }$ & \\
\hline Mikania scandens & Asteraceae & Liana & $\sqrt{ }$ & \\
\hline
\end{tabular}

feeding on fruits (Bastian et al. 2010).

In CMRAs, most of the trees found in CMRAs are unusual crop for orangutan which eaten in its natural habitat. There were only five species of trees is known as the orangutan food tree in their natural habitat, namely, Croton argyratus, Syzygium sp., Ficus sp., M. gigantea, and G. pentandra. However, it must be remembered that the five species of trees were not the dominant species in that area. In addition, the trees were not the species of important food plants for orangutan. Therefore, it could be assured that the 5 species of trees were not the reliable species for orangutan to survive in CMRA.

Based on the direct observations and interview result several workers, it found that orangutan adapted to eat species of the trees growing there. Several species eating by orangutan, among others, johar ( $S$. siamea), sengon (Falcataria moluccana), lamtoro (Leucaena leucocephala), flamboyan (D. regia), akar belaran (Merremia peltata), kaliandra (Calliandra calothyrsus), Calopogonium caeruleum, and Centrocema acutifolium. It species were exotic species that are not found in the natural habitat of orangutan. The plants were also not the fruit trees which had soft flesh favored by orangutan (Meijaard et al. 2001).

According to Ancrenaz et al. (2007), bornean orangutan species at a certain degree had an ability to survive at disturbed habitat by eating alternative/fallback food available in that area. For example, when the natural food was not enough, orangutan living within and outside the palm tree plantation and they ate young palm (Yuwono et al. 2007; Ancrenaz et al. 2010), orangutan living at and around the pulp and paper plantation ate the bark of $A$. mangium (Denis et al. 2010; Meijaard et al. 2010), orangutan living in the area of agriculture changed their active eating time and ate the crop yield that belonged the society, like star fruit, jack fruit, durian and pete (Campbell-Smith et al. 2011). Marshall and Wrangham (2007) define fallback food as foods whose use is negatively correlated with the availability of preferred foods. Fallback foods shape primate food processing adaptations, that the dietary importance of fallback foods is central in determining the expression of a variety of traits (Harrison \& Marshall 2011). Bornean orangutans typically consume bark and leaves as fallback food in Borneo, while sumateran orangutans with greater importance of figs (Harrison 2009; Vogel et al. 2008; Wich et al. 2006). The behavior flexibility shown by orangutan seemed one of the adaptation ways towards the less productive forest in Borneo (Hockings \& Humle 2010).

Nest tree Trees are not only the important food sources for the orangutan, but they are also the important need as the place build a nest (Prasetyo et al. 2007). According to Santosa and Rahman (2012), there were three dominant ecological variables that influence the presence or absence of orangutan nests, namely, the distance of nest trees with nearby sources of feed, the number of food tree close to the nest, and the presence of food trees near the nest.

This research also identified five species of trees used by orangutan as nest trees in Gajah Hitam CMRA and there were eight species of trees in Taman Payau CMRA used as nest trees. Therefore, there were minimum 10 species of trees used by orangutan as nest trees in both CMRA (see Table 7).

The above result showed that in CMRA where there were lack of trees, orangutan used the trees growing there and orangutan did not specifically choose the species of trees 
used as nest trees. Rayadin et al. (2013) agreed with this in which species of johar (S. siamea), the most dominant ones in the research location was the most species of trees used by orangutan as nest trees.

In richer habitat of tree species, a number of trees used by orangutan as nest trees were more various. For example, the sub species of morio in KNP Prevab area used minimum 49 species of trees as nest trees and there were 80 species in Bhirawa forest, Kutai Kertanegara Regency (Niningsih 2009). In Sebangau Central Kalimantan, there were minimum 52 species of trees used as nest trees by Pongo pygmaeus wurmbii (Cheine et al. 2013). Rayadin \& Saitoh (2009) recorded there were 31 tree species in 20 families used as nest tree by Pongo pygmaeus morio in East Kalimantan.

Forest structure Orangutan is arboreal mammals spending their time mostly on the trees, like eating, drinking and sleeping. This behavior is very influenced by the structure of vegetation in their habitat. The structure of vertical of forest would affect the height of orangutan to do an activity and horizontal structure would affect orangutan significantly when orangutan moved.

Thoroughly, the density of trees with $\mathrm{dbh} \geq 5 \mathrm{~cm}$ in Taman Payau CMRA and Gajah Hitam was 880 trees $^{-1} \mathrm{l}^{-1}$, the average dbh of $\pm 12 \mathrm{~cm}$, basal area of $\pm 14.96 \mathrm{~m}^{2} \mathrm{ha}^{-1}$. Trees arranging the stand in CMRA were almost in the same age. Therefore, they tended to have almost the same diameter, height, and canopy.

Small diameter trees $(\mathrm{dbh} \leq 20 \mathrm{~cm})$ dominated significantly in CMRA. There were a lot number of trees with dbh 5.1-10 m in both CMRA, while trees with $\mathrm{dbh}>20 \mathrm{~cm}$ were in small percentage. This condition was very different from the natural habitat of orangutan in Prevab KNP, in which there were big size trees with $\mathrm{dbh}>50 \mathrm{~cm}$. The distribution of dbh from both CMRA can be seen in Figure 5 .

Taman Payau CMRA had tree density of \pm 655 trees $^{-1}$, the average dbh of $\pm 13.25 \mathrm{~cm}$, basal area of $\pm 11.97 \mathrm{~m}^{2} \mathrm{ha}^{-1}$. CMRA Gajah Hitam had tree density of \pm 1105 trees $\mathrm{ha}^{-1}$, the average dbh of $\pm 11.57 \mathrm{~cm}$, basal area of $\pm 17.95 \mathrm{~m}^{2} \mathrm{ha}^{-1}$. The height of trees with dbh $\geq 5 \mathrm{~cm}$ in Taman Payau CMRA was around $4.5-17.2 \mathrm{~m}$ with the average height of $\pm 9.89 \mathrm{~m}$. Of the number of trees found within the botany plot, there were as much as $52.34 \%$ that were in the height class of 5.1-10 m and $41.41 \%$ was in the height class of $10.1-15 \mathrm{~m}$. The distribution of tree height with $\mathrm{dbh} \geq 5 \mathrm{~cm}$ in Gajah Hitam CMRA was not too different. The height was about $1.7-18 \mathrm{~m}$ with the average height of $\pm 10.75 \mathrm{~m}$. Of the trees found in botany plot of Gajah Hitam, as much as $3.50 \%$ was in the height class of 5.1-10 m and $50.22 \%$ was in the height of 10.1-15 m. Vertical structure from the stand in both CMRA can be seen in Figure 6.

Vertical structure of forest in the area of research was very different from the previous condition before there was a mining activity. This area was wet tropical rain forest which was very dense inhabited by orangutan (Meijaard et al. 2001). There were five layers of canopy in the natural habitat in Prevab Kutai National Park, i.e., A ( $>30 \mathrm{~m})$, B (20-30 m), C (4-20 m), D (1-4 m), and E (0-1 m) layers (Niningsih et al. 2016). At the moment forest stand in CMRA had only three layers of the canopy with $\mathrm{C}$ stratum as the top canopy layer.

Horizontal structure of stand was very important for orangutan because the ability of orangutan to move from one tree to another depended on the continuity of canopy. Canopy continuity was very determined by the density and diameter of canopy from trees in the same height class.

Canopy diameter from trees with $\mathrm{dbh} \geq 5 \mathrm{~cm}$ in CMRA was around $0.96-18.65 \mathrm{~m}$ with the average canopy diameter of $\pm 5.70 \mathrm{~m}$. Trees with canopy diameter of $<5 \mathrm{~m}$ and $5.1-10$ $\mathrm{m}$ were the most, i.e., $46.70 \%$ and $46.42 \%$. Trees that had canopy diameter of 10.1-15 $\mathrm{m}$ and $15.1-20 \mathrm{~m}$ were very few, only $\pm 5.44 \%$ and $1.43 \%$ of the number of trees. This condition is different from the natural habitat in KNP which contained trees had canopy diameter wide (Ferisa 2014; Niningsih et al. 2016).

Figure 7 presents the stand horizontal structure in Taman Payau CMRA and Gajah Hitam. The figure shows the forest canopy in both CMRA that is not always continue because the trees arranging the stand were not dense enough and their canopy was not wide enough. Canopy discontinuity was also caused by the present of liana in CMRA. In the natural habitat of orangutan, woody liana was the important

Table 7 Species and family of trees used for nest by orangutan in CMRA Taman Payau (TP) and CMRA Gajah Hitam (GH)

\begin{tabular}{|c|c|c|c|}
\hline Species & Family & ТP & $\mathrm{GH}$ \\
\hline Delonix regia (Hook.) raf. & Fabaceae & $\sqrt{ }$ & - \\
\hline Falcataria moluccana (Miq.) & Fabaceae & $\sqrt{ }$ & - \\
\hline Gmelina arborea Roxb. & Verbenaceae & $\sqrt{ }$ & $\sqrt{ }$ \\
\hline Hibiscus macrophyllus Roxb. & Malvaceae & $\sqrt{ }$ & - \\
\hline Leucaena leucocephala (lam.) de Wit & Fabaceae & $\sqrt{ }$ & - \\
\hline Macaranga gigantea (Rchb.f. \& Zoll.) & Euphorbiaceae & - & $\sqrt{ }$ \\
\hline Mallotus dispar (Blume) & Euphorbiaceae & $\sqrt{ }$ & - \\
\hline Senna siamea Lam. & Fabaceae & $\sqrt{ }$ & $\sqrt{ }$ \\
\hline Syzygium sp. & Myrtaceae & - & $\sqrt{ }$ \\
\hline Vitex pinnata $\mathrm{L}$. & Verbenaceae & $\sqrt{ }$ & $\sqrt{ }$ \\
\hline
\end{tabular}




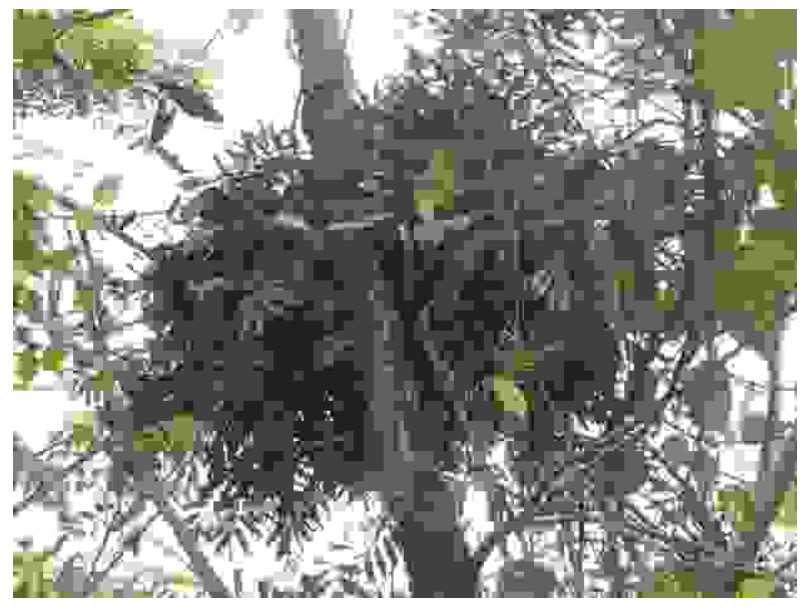

Figure 4 Orangutan nest observed in Senna siamea.

connecting equipment for orangutan to move if the canopy of trees did not intersect each other (Richard 1952; Rijksen 1978). In the area of Mentoko and Prevab, KNP, the trees forming the $\mathrm{C}$ stratum mostly associated with epiphytic and liana (Ferisa 2014).

Forest structure and support availability have important effects on orangutan locomotion (Manduell et al. 2012). Forest canopy discontinuity can certainly make orangutan go down to the ground to move from one tree to another. According to Ancrenaz et al. (2014), the increase of terrestriality would increase the risk of hunting and the new disease exposure because big ape was vulnerable towards most human disease. Moreover, it could be said that one of the reasons why bornean orangutan still kept the arboreal behavior was because orangutan wanted to decrease the risk of human activity exposure.

Implication Orangutan habitat characteristics in CMRAs are very different from those of natural habitat. CMRA is not the good habitat for orangutan if seen from the aspect of either structure or vegetation composition. Coal mining has removed the large trees are very important for the orangutan as the food resources, nest site, and as the tools to arboreal movement (Felton et al. 2003).

Orangutan habitat in the coal mining area are fragmented into smaller patches, some of them suffered isolation (insularization). Fragmentation and isolation of patches can cause the ability of orangutans to move between patches is decreasing. Orangutans are isolated in the small patch is very susceptible to inbreeding depression, genetic drift, and other problems associated with small populations (Gunawan \& Prasetyo 2013; Indrawan et al. 2007; Aguilar et al. 2008). Small populations are also vulnerable to the threat of demographic change (rates of death and birth) and environmental changes (disease, predation, competition, food, and natural disasters) (Indrawan et al. 2007). In the CMRA, the fruit trees and woody lianas which are important food resources for orangutans were very restricted (Morrogh-Bernard et al. 2009). Analysis of the orangutan habitat characteristics in the coal mining area indicates that it need for efforts to increase the habitat carrying capacity

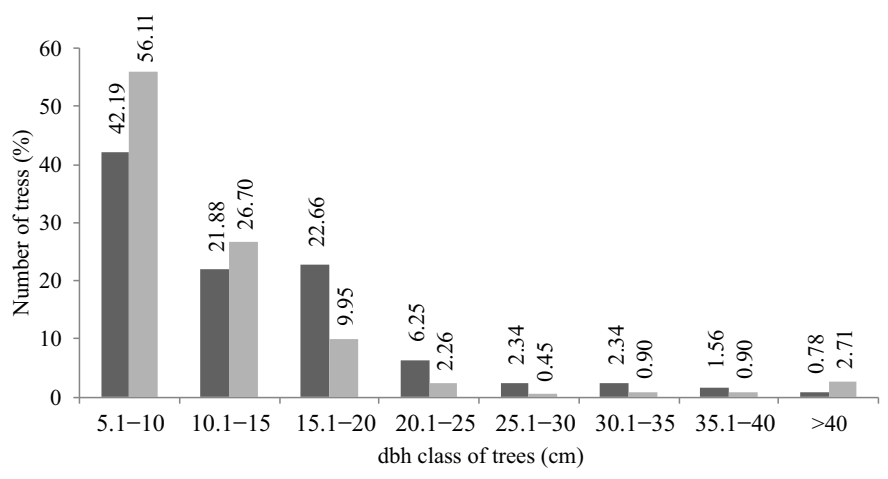

Figure 5 The distribution dbh of trees in Taman Payau and Gajah Hitam. Taman payau ( $\square$ ), Gajah Hitam ( $\square$ ).

approach the natural habitat.

CMRA is very lacking on fruit trees and habitat enrichment with the fruit trees can improve the quality orangutan habitat in the future. Ideally, the choice of plants should consider the ecological characteristics of the species (Dennis et al. 2011), among other things: a food source has been known, the food source for other species, fast growing species, as well as climatic and edaphic is suitable. Unfortunately, the most of the fruit trees which the natural food of the orangutan are unknown its ecological characteristics because it has never been cultivated or observed its increment and growth. The species of fruit trees recommended are the species is favored by orangutans but it is disliked by humans. Enrichment with tree species that its bark favored by orangutans is not recommended because of the tree which its bark consumed by orangutan will be death.

Sengkuang tree (Dracontomelon dao) is one of the species recommended for planting in the CMRA. Although the increment and age begin to bear the fruit of this species is unknown, sengkuang is the fruit which favored by the orangutan in the Prevab and Mentoko, KNP (Rodman 1977; Campbell 1992; Ferisa 2014). Sengkuang trees can found in almost all area of East Kalimantan, especially in riparian areas. It showed that sengkuang is suitable in edaphic and climatic. In addition, seeds of the sengkuang are not difficult to get. Figs (Ficus spp.) also highly recommended. Figs are most important food to many primates and the staple food for the orangutan (Mackinnon 1974; Rijksen 1978). Three species of Ficus (F. rubiginosa, F. uniglandulosa, and F. pubilimba) were consumed most frequently by orangutans in Prevab area (Niningsih 2016).

Orangutan movement between habitat fragments assumed was very limited in this study and was not enough to prevent the effects of isolation. The company must make sure that each habitat patch, especially CMRA connect with the more spacious natural forests or other CMRA to prevent isolation. Orangutan needs the corridor to move from one patch to another patch (Luckett et al. 2004; Nasi et al. 2008). Wildlife corridors are one of the strategies for orangutan conservation in the mining area to prevent the effect of the 
habitat patch isolated on the orangutan.

Effective corridor is a corridor that has enough suitable habitat for the target species (orangutans) for lives permanently or passes normally (Harrison 1992). The minimum width of corridors for orangutans based on home range orangutans and sufficient to prevent the penetration of vegetation at the corridor edge (Harrison 1992). Construction of a corridor requires restoration as in low-quality habitat patches will be connected. The manager must plant the food trees and nest trees of the target species (orangutan) along the corridor (Bond 2003). Food trees, nest trees, and canopy connectivity are very important to consider in managing the corridor.

\section{Conclusion}

Coal mining operations caused the natural habitat of the orangutan which originally compact and intact fragmented into smaller patches in the form of CMRA and degraded
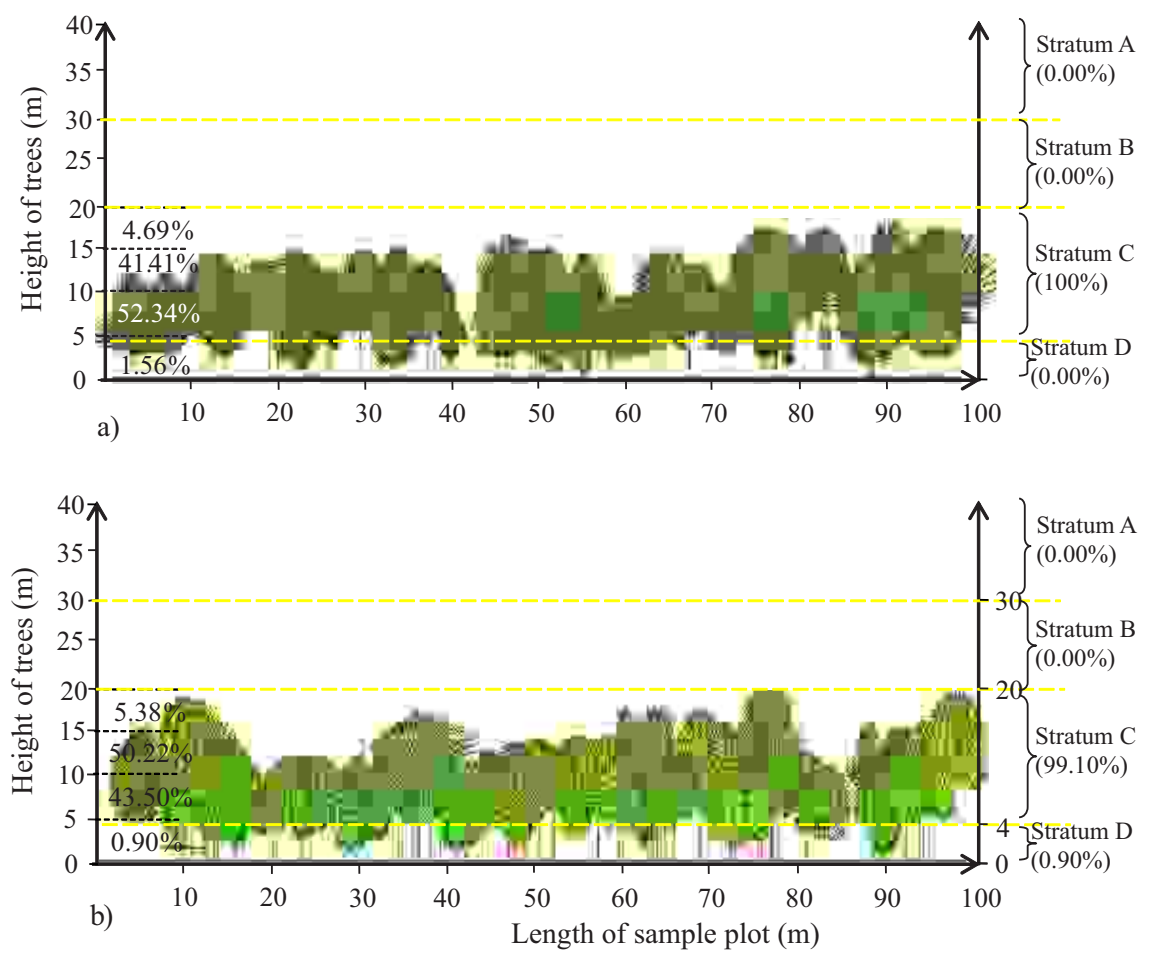

Figure 6 Vertical profile of forest in CMRA Taman Payau (a) and Gajah Hitam (b).

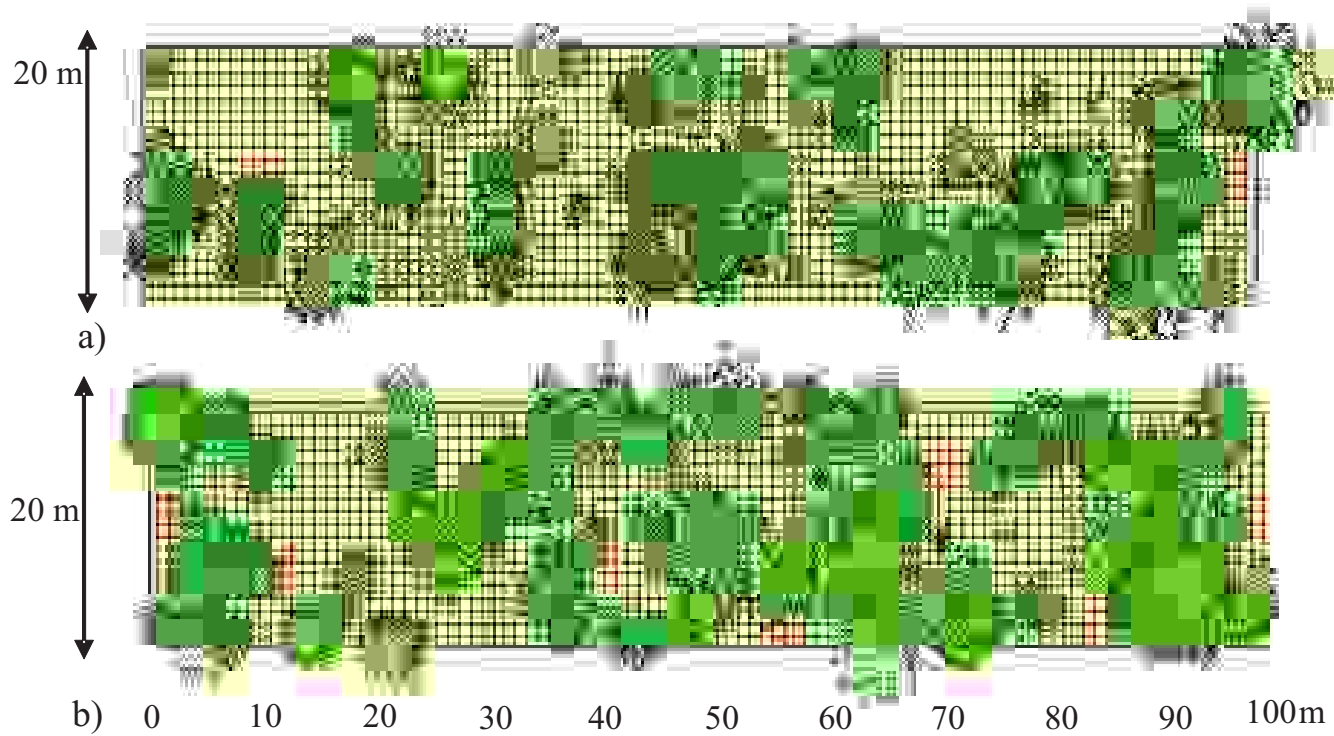

Figure 7 Horizontal profile of forest in CMRA Taman Payau (a) and Gajah Hitam (b). 
forests remaining that surrounded by large disturbed area. The structure of forest stands in the CMRA tended similarly and the forest canopy is not continued. It is because of the forest compiled by the small trees of the same species and the same age class. Exotic species dominate in the CMRA, no fruit tree and woody liana in that area. The most dominant species in the CMRA were $S$. siamea, $F$. moluccana, and $S$. surattensis. CMRA is not the good habitat for orangutan if seen from the aspect of either land cover as well as the structure and vegetation composition. The quality of habitat can be improved by modifying the structure of stand and vegetation composition, build the ecosystem corridors, increase public/workers awareness, and involve various stakeholders in the orangutan conservation at the landscape level. One of the ways recommended is to enrich with various fruit tree species whose fruit is favored by orangutan but contrary for the human. Habitat enrichment of tree species whose bark was liked by orangutan is not recommended.

\section{Acknowledgement}

We are very grateful to the management of PT KPC at Sangatta for granting us permission to conduct research in coal mining area. We thank to College of Agricultural (STIPER) Kutai Timur, Bogor Agricultural University, and provincial government East Kalimantan. We are also indebted to the individuals and organizations who provided logistical and organizational support in the field: PT KPC (I. Manege, K. Pranoto, W. Wardana, Y. Katindo, etc.), STIPER Kutai Timur (Arbain, I.M. Ramadhan), field assistants at PT KPC (D. Nugraha, T.C. Mandolang, Saiful, Sugeng, Munir, Constant, Y. Musa, Fauzan, Kurnia, etc). The research complied with Indonesian legal requirements and was approved by the relevant institutional animal care committees of the nation of Indonesia.

\section{References}

Abram NK, Meijaard E, Wells JA, Ancrenaz M, Pellier A-S, Runting RK, Gaveau D, Wich SA, Nardiyono, Tjiu A, Nurcahyo A, Mengersen K. 2015. Mapping perceptions of species' threats and population trends to inform conservation efforts: the bornean orangutan case study. Diversity Distribution. 21(5):487-499. http://dx.doi.org/ 10.1111/ddi.12286.

Aguilar R, Quesada M, Ashworth L, Herrerias-Diego Y, Lobo J. 2008. Genetic consequences of habitat fragmentation on in plant populations: susceptible signals in plant traits and methodological approaches. Molecular Ecology 17(24):5177-5188. http://dx.doi.org/10.1111/j.1365294X.2008.03971.x.

Ancrenaz M, Oram F, Ambu L, Lackman I, Ahmad E, Elahan H, Kler H, Abram NK, Meijaard E. 2014. Of Pongo, palms and perceptions: a multidisciplinary assessment of bornean orang-utans Pongo pygmaeus in an oil palm context. Oryx 42:1-8. http://dx.doi.org/10.1017/ S0030605313001270.

Ancrenaz M, Dabek L, O'Neil S. 2007. The costs of exclusion: recognizing a role for local communities in biodiversity conservation. PLoS Biology 5(11):e 289. http://dx.doi.org/10.1371/journal.pbio.0050289.

Ancrenaz M, Calaque, R \& Lackman-Ancrenaz, I. 2004. Orangutan nesting behavior in disturbed forest of Sabah, Malaysia: implications for nest census. International Journal of Primatology 25(5):983-1000.

Ancrenaz M, Gumal M, Marshall AJ, Meijaard E, Wich SA, Husson S. 2016. Pongo pygmaeus. The IUCN Red List of Threatened Species 2016: e.T117975A17966347. http://dx.doi.org/10.2305/IUCN.UK.20161.RLTS.T1775A17966347. en. [23 Nov 2016].

Bastian ML, Zweifel N, Vogel ER, Wich SA, van Schaik CP. 2010. Diet traditions in wild orangutans. American Journal of Physical Anthropology 143:175-187. http://dx.doi.org/10.1002/ajpa.21304.

Bond M. 2003. Principles of Wildlife Corridor Design. http://www.biologicaldiversity.org [30 Desember 2016].Campbell JL. 1992. Ecology of bornean orangutans (Pongo pygmaeus) in drought and fire affected lowland rainforest [dissertation]. Pennsylvania: The Pennsylvania State University.

Campbell NA.Reece JB, Urry LA, Cain ML, Wasserman SA, Minorsky PV, Jackson RB. 2008. Biology Eighth edition. In: Hardani W, Adhika P, editor. Biologi Edisi Kedelapan Jilid 3. Jakarta: Erlangga.

Campbell-Smith G, Campbell-Smith M, Singleton I, Linkie1 M. 2011. Raiders of the lost bark: orangutan foraging strategies in a degraded landscape. PLOS ONE 6(6):1-8. http://dx.doi.org/10.1371/journal.pone.0020962.

Cheyne SM, Rowland D, Höing A, Husson SJ. 2013. How orangutans choose where to sleep: comparison of nest-site variables. Asian Primates Journal 3(1):13-17.

Davies SJ, Ashton PS. 1999. Phenology and fecundity in 11 sympatric pioneer species of Macaranga (Euphorbiaceae) in Borneo. American Journal of Botany 86(12): 1786-1795.

Davies SJ. 1998. Photosynthesis of nine pioneer Macaranga species from Borneo in relation to life-history. Ecology 79(7):2292-2308. http://dx.doi.org/10.1890/00129658(1998)079[2292: PONPMS]2.0.CO;2.

Dennis R, Grant A, Hadiprakasa Y, Hartman P, Kitchener D, Lamrock T, MacDonald F, Meijaard E, Prasetyo D. 2010. Best Management Practices for Orangutan Conservation: Industrial Timber Plantation. Jakarta: USAID.

Felton AM, Engström LM, Felton A, Knott CD. 2003. Orangutan population density, forest structure and fruit availability in hand-logged and unlogged peat swamp forests in West Kalimantan, Indonesia. Biological Conservation 114(1):91-101. http://dx.doi.org/10.1016/ S0006-3207(03)00013-2. 
Ferisa A. 2014. Pemanfaatan ruang oleh orangutan Pongo pygmaeus morio (Owen, 1837) di Stasiun Penelitian Mentoko dan Prefab Taman Nasional Kutai Kalimantan Timur (thesis). Bogor: Institut Pertanian Bogor.

Forman RTT. 1995. Some general principles of landscape and regional ecology. Lanscape Ecology 10(3):133-142. http://dx.doi.org/10.1007/BF00133027.

Gunawan H, Prasetyo LB. 2003. Fragmentasi Hutan: Teori yang Mendasari Penataan Ruang Menuju Pembangunan Berkelanjutan. Jakarta: Balitbang Kehutanan.

Harja D, Vincent G. 2008. Spatially Explicit Individual-based Forest Simulator-User Guide and Software. Bogor: World Agroforestry Centre (ICRAF) and Institut de Recherche pour le Développement (IRD).

Harrison E, Marshall AJ. 2011. Strategies for the use of fallback foods in Apes. International Journal of Primatology 32:531-565. http://dx.doi.org/10.1007/ s10764-010-9487-2.

Harrison RL. 1992. Toward a theory of inter-refuge corridor design. Conservation Biology 6(2):293-295. http://dx.doi.org/10.1046/j.1523-1739.1992.620293.x.

Harrison M E, Vogel ER, Morrogh-Bernard H, van Noordwijk MA (2009). Methods for calculating activity budgets compared: a case study using orangutans. American Journal of Primatology 71:353-358. http://dx.doi.org/10.1002/ajp.20655.

Hockings K, Humle T. 2010. Panduan Pencegahan dan Mitigasi Konflik antara Manusia dan Kera Besar. Switzerland: IUCN, Species Survival Commission.

Indrawan M, Primack RB, Supriatna J. 2007. Biologi Konservasi (edisi revisi). Jakarta: Yayasan Obor Indonesia.

Kanamori T, Kuze N, Bernard H, Malim TP, Kohshima S. 2010. Feeding ecology of bornean orangutans (Pongo pygmaeus morio) in Danum Valley, Sabah, Malaysia: A 3year record including two mast fruitings. American Journal of Primatology 74:1128-1142. http://dx.doi.org/ 10.1002/ajp.20848.

KPC. 2011. Innovate Improve Sustain: Sustainability Report PT Kaltim Prima Coal. Kutai Timur: KPC.KPC. 2015. Membara untuk Indonesia: Sustainability Report PT Kaltim Prima Coal. Sangatta, Kutai Timur: PT KPC.

Luckett J, Danforth E, Linsenbardt K, Pruetz J. 2004. Planted trees and corridors for primates at El Zota Biological Field Station, Costa Rica. Neotropical Primates 12(3):143-146. http://dx.doi.org/10.1896/1413-4705.12.3.143.

Manduell KL, Harrison ME, Thorpe SKS. 2012. Forest structure and support availability influence orangutan locomotion in Sumatra and Borneo. American Journal of Primatology 72:820-840. http://dx.doi.org/10.1002/ ajp.22072.

Marshall AJ, Wrangham RW. 2007. Evolutionary consequences of fallback foods. International Journal of Primatology 28(6):1219-1235. http://dx.doi.org/ 10.1007/s10764-007-9218-5.

Meijaard E, Albar G, Nardiyono, Rayadin Y, Ancrenaz M, Spehar S. 2010. Unexpected ecological resilience in bornean orangutans and implications for pulp and paper plantation management. PLOS ONE 5(9):e12813. http://dx.doi.org/10.1371/journal.pone.0012813.

Meijaard E, Rijksen HD, Kartikasari SN. 2001. Di Ambang Kepunahan, Kondisi Orangutan Liar di Awal Abad 21. Jakarta: The Gibbon Foundation.

Morrogh-Bernard HC, Husson SJ, Knott CD, Wich SA, van Schaik CP, van Noordwijk MA, Lackman-Ancrenaz I, Marshall AJ, Kanamori T, Kuze N, Sakong R. 2009. Orangutan activity budgets and diet: a Comparison between species, populations and habitats. In: Wich SA, Utami Atmoko SS, Mitra Setia T, van Schaik CP, editor. Orangutans: Geographic Variation in Behavioral Ecology and Conservation. New York. Oxford Univ Pr: 119-132.

Nasi R, Koponen P, Poulsen JG, Buitenzorgy M, Rusmantoro W. 2008. Impact of landscape and corridor design on primates in a large-scale industrial tropical plantation landscape. Biodiversity Conservation 17:1105-1126. http://dx.doi.org/10.1007/s10531-007-9237-8.

Niningsih L, Alikodra HS, Utami-Atmoko SS, Mulyani AR. 2016. Habitat characteristic of Pongo pygmaeus morio in Prevab Area, Kutai National Park, Kalimantan, Indonesia. International Journal of Sciences: Basic and Applied Research (IJSBAR) 30(3):8-20.

Niningsih L. 2009. Studi tentang interrelasi karakteristik sarang dengan laju pelapukan sarang serta implikasinya terhadap pendugaan kerapatan orangutan (thesis). Samarinda: Universitas Mulawarman.

Prasetyo D, Ancrenaz M, Morrogh-Bernard HC, UtamiAtmoko SS, Wich SA, van Schaik CP. 2009. Nest building in orangutans. In: Wich SA, Utami Atmoko SS, Mitra Setia T, van Schaik CP, editor. Orangutans: Geographic Variation in Behavioral Ecology and Conservation. New York. Oxford University Press:269-277.

Rayadin Y, Boer C, Masrun H, Rochmadi S, Qomari N, Samsudin J, Sutrisman A, Nugroho N, Hanggito MS, Alifianuari, Faisal M. 2013. Perilaku Ekologi dan Distribusi Populasi Orangutan (Pongo pygmaeus morio) pada berbagai Fungsi Lanskap di Kalimantan Timur. Samarinda: Ecositrop-PPHT-UNMUL-TNC.

Rayadin Y, Boer C, Masrun H, Rochmadi S, Sutrisman A, Hanggito MS, Syamsudin J. 2012. Laporan Analisis Distribusi Populasi dan Perilaku Orangutan pada Kawasan Reklamasi Pasca Tambang PT Kaltim Prima 


\section{Coal. Samarinda: Ecositrop-PPHT-UNMUL.}

Rayadin Y, Saitoh T. 2009. Individual variation in nest size site features of the bornean orangutan (Pongo pygmaeus). American Journal of Primatology 71:393-399. http://dx.doi.org/10.1002/ ajp.20666.

Rayadin Y, Spehar NS. 2015. Brief communication: body mass of wild bornean orangutans living in humandominated landscapes: implications for understanding their ecology and conservation. American Journal of Physical Anthropology 157(2):339-346. http://dx.doi. org/10.1002/ ajpa.22709.

Reader SM, MacDonald K. 2003. Environmental variability and primate behavioral flexibility. In: Reader SM, Laland KN, editor. Animal innovation. New York. Oxford Univ Pr: 83-116.

Richards PW. 1952. The Tropical Rain Forest. New York: Cambridge University Press.

Rijksen HD. 1978. A Field Survey on Sumatran Orang-utans (Pongo pygmaeus abelii Lesson, 1827): Ecology Behavior and Conservation. Wageningan: H Veenman Zonen BV.

the Kutai Nature Reserve, East Kalimantan. In: Clutton-Brock TH, editor. Primate Ecology: Studies of Feeding and Ranging Behavior in Lemurs, Monkeys and Apes. London. London Academic Pr: 383-413.

Santosa Y, Rahman DA. 2012. Precision of nest method in estimating orangutan population and determination of important ecological factors for management of conservation forest Journal Manajemen Hutan Tropika 18(1):39-51. http://dx.doi.org/10.7226/jtfm.18.1.39.

Sihombing BH. 2012. Potensi Kawasan Lindung di Areal Konsesi PT Kaltim Prima Coal dan Sekitarnya Sangatta Kalimantan Timur [dissertation]. Samarinda: Universitas Mulawarman.

Soehartono T, Susilo HD, Andayani N, Utami-Atmoko SS, Sihite J, Saleh C, Sutrisno A. 2009. Strategi dan Rencana Aksi Konservasi Orangutan Indonesia 2007-2017. Jakarta: Dephut RI, Dirjend PHKA.

Soendjoto MA, Dharmono, Mahrudin, Riefani MK, Triwibowo D. 2014. Plant species richness after revegetation on the Reclaimed Coal Mine Land of PT Adaro Indonesia, South Kalimantan. Journal Manajemen Hutan Tropika 20(3):150-158. http://dx.doi.org/10.7226/ jtfm.20.3.150.

Soerianegara I, Indrawan A. 1998. Ekologi Hutan Indonesia. Bogor: Fakultas Kehutanan, Institut Pertanian Bogor.

Sol D. 2003. Behavioural innovation: a neglected issue in the ecological and evolutionary literature? In: Reader SM, Laland KN, editor. Animal innovation. New York. Oxford Univ Pr: 63-82. http://dx.doi.org/10.1093/acprof:oso/ 9780198526223.003.0003.

Struebig MJ, Fischer M, Gaveau DLA, Meijaard E, Wich SA, Gonner C, Sykes R, Wilting A, Kramer-Schadt S. 2015. Anticipated climate and land-cover changes reveal refugeareas for Kalimantan's orang-utans. Global Change Biology 21(8):2891-2904. http://dx.doi.org/ $10.1111 / \mathrm{gcb} .12814$

Suhud M, Saleh C. 2007. Dampak Perubahan Iklim terhadap Habitat Orangutan. Jakarta: WWF-Indonesia.

Swaine MD, Whitmore TC. 1988. On the definition of ecological species groups in tropical rain forests. Vegetation 75(1):81-86. http://dx.doi.org/10.1007/ BF00044629.

van Schaik CP. 2001. Other chimpanzees. Evolutionary Biology 14(3):520-521. http://dx.doi.org/10.1046/j.14209101.2001.0288b.

Vogel ER, van Woerden JT, Lucas PW, Utami Atmoko SS, van Schaik CP, Dominy NJ. 2008. Functional ecology and evolution of hominoid molar enamel thickness: Pan troglodytes schweinfurthii and Pongo pygmaeus wurmbii. Journal of Human Evolution 55(1):60-74. http://dx.doi.org/10.1016/j.jhevol.2007.12.005.

Wahyudi B. 2009. Analisis pohon pakan orangutan (Pongo Pygmaeus) di kawasan Prevab Taman Nasional Kutai Kalimantan Timur (Skripsi). Kutai Timur: STIPER Kutai Timur.

Whitmore TC. 1975. Tropical Rain Forest of the Far East. Oxford: Clarendon Press.

Wich SA, Gaveau D, Abram N, Ancrenaz M, Baccini A, Brend S, Curran L, Delgado RA, Erman A, Fredriksson GM et al.. 2012. Understanding the impacts of land-use policies on a threatened species: is there a future for the bornean orang-utan?. PLoS ONE 7(11):e49142. http://dx.doi.org/10.1371/journal. pone.0049142.

Wich SA, Utami Atmoko SS, Mitra Setia T, Djojosudharmo S, Geurts ML. 2006. Dietary and energetic responses of Pongo abelii to fruit availability fluctuations. International Journal of Primatology 27(6):1535-1550. http://dx.doi.org/10.1007/s10764-006-9093-5.

Yuwono EH, Susanto P, Saleh C, Andayani N, Prasetyo D, Utami-Atmoko SS. 2007. Guidelines For The Better Management Practices on Avoidance, Mitigation and Management of Human-Orangutan Conflict An and Around Oil Palm Plantations. Jakarta: WWF Indonesia. 